LIBRI

www.libridergi.org

Kitap Tanıtımı, Eleştiri ve Çeviri Dergisi

Journal of Book Notices, Reviews and Translations

Volume I (2015)

W. BALL, Avrupa'daki Asya ve Batı'nın Şekillenişi Cilt 2, Tek Dünyaya Doğru - Antik İran ve Batı. İstanbul 2015. Ayrıntı Yayınları, 319 sayfa (95 resim, 11 harita ve plan ile birlikte). Çev.: Ahmet Aybars ÇAĞLAYAN. ISBN: 9789755399683

\section{Özge ACAR}

Libri: Kitap Tanııımı, Eleştiri ve Çeviri Dergisi'nde bulunan içeriklerin tümü kullanıcılara açık, serbestçe/ücretsiz 'açık erişimli' bir dergidir. Kullanıcılar, yayıncıdan ve yazar(lar)dan izin almaksızın, dergideki makaleleri tam metin olarak okuyabilir, indirebilir, dağıtabilir, makalelerin çıktısını alabilir ve kaynak göstererek makalelere bağlantı verebilir.

Libri, uluslararası hakemli elektronik (online) bir dergi olup değerlendirme süreci biten makaleler derginin web sitesinde (www.libridergi.org) yıl boyunca ilgili sayının içinde (Volume I: Ocak-Aralık 2015) yayımlanır. Aralık ayı sonunda ilgili yıla ait sayı tamamlanır.

Dergide yayımlanan eserlerin sorumluluğu yazarlarına aittir.

Künye W. BALL, Avrupa'daki Asya ve Batı́nın Şekillenişi Cilt 2, Tek Dünyaya Doğru - Antik İran ve Batı. İstanbul 2015. Ayrıntı Yayınları, 319 sayfa (95 resim, 11 harita ve plan ile birlikte). Çev.: Ahmet Aybars ÇAĞLAYAN. ISBN: 9789755399683 Tanıtan: Özge ACAR, Libri I (2015) 51-52. DOI: 10.20480/lbr.2015115463

Geliş Tarihi: 17.09.2015

Kabul Tarihi: 23.09.2015

Online Yayın Tarihi: 28.12.2015

URL: http://dx.doi.org/10.20480/lbr.2018115463

Editörya Phaselis Project

www.phaselis.org 


\title{
W. BALL, Avrupa'daki Asya ve Batı'nın Şekillenişi Cilt 2, Tek Dünyaya Doğru - Antik İran ve Batı. İstanbul 2015. Ayrıntı Yayınları, 319 sayfa (95 resim, 11 harita ve plan ile). Çev.: Ahmet Aybars ÇAĞLAYAN. ISBN: 9789755399683
}

\begin{abstract}
Özge ACAR*
Orta Doğu uzmanı, arkeolog Warwick Ball'un, ilk cildi Out of Arabia: Phoenicians, Arabs, and the Discovery of Europe başlığı altında 2009 yılında; Ahmet Aybars Çağlayan tarafından Türkçe'ye çevrilerek Arabistan'dan Öteye: Fenikeliler, Araplar ve Avrupa'nın Keşfi başlı̆̆ı altında 2014 yılında basılan, dizi adı alt başlığında belirtildiği gibi kültürlerin Asya'dan Avrupa'ya yayılışını inceleyen dört ciltlik bir seri olan Asia in Europe and the Making of the West (Avrupa'daki Asya ve Batı'nın Şekillenişi) dizisinin ikinci cildi Towards one World: Ancient Persia and the West başlıklı bu eser, 2010 yılında basılmış ve yine Ahmet Aybars Çağlayan tarafından çevrilerek bu yıl Türk okuyucusuna sunulmuştur. Özellikle, bugün güvenlik nedeniyle gezilmesi zor olan Afganistan'daki arkeolojik alanlar üzerine yaptığı çalışmasıyla tanınan araştırmacı yazar, bu dizide daha genel bir konu hakkında fikirlerini paylaşmakta ve okuyucuyu Avrupa'nın gerçekte ne kadar Avrupalı olduğu ve Doğu ile Batı arasında ne tür bir ilişki olduğu gibi sorular üzerinde düşünmeye itmektedir. Hakkında ciltlerce kitaplar yazılan, sayısız tartışmalar yapılan ve pek çok tarihçinin, düşünürün, siyaset bilimcinin zihnini meşgul eden kadim Doğu-Batı mücadelesini yazar, basmakalıp ifadelerin dışına çıkararak farklı bir boyuta taşımaktadır. Bu hususta, bu ebedi mücadele fikrinin bir mit olduğunu ve dolayısıyla niyetinin Doğu ile Batı'yı yarıştırmak veya her şeyin Doğu'dan çıktığını ispata çalışmak olmadığını açıkça belirtmektedir. Doğu ile Batı arasındaki ilk temasın antik İran ile başladığını vurgulayan yazar, antik İran'ın tek dünya düşüncesi temelinde Doğu ve Batı kavramlarının gerçekte var olup olmadığı konusunu sorguladığı bu kitapta temel olarak; sırasıyla Eski Yunan, İskender ve Roma ile olan ilişkiler ve savaşlar bazında antik İran tarihini, Zerdüştçülükten itibaren İran’a has dini düşünceleri ve tek dünya düşüncesini ele almaktadır.

içindekiler (7), Harita ve Planlar (8), Resim Listesi (9-13) kısımlarının ardından gelen Diziye Giriş (15-16) bölümünde söz konusu dizinin ortaya çıkıs amacı belirtilmekte, Önsöz ve Katkıda Bulunanlara Teşekkürler (17-19) bölümünde ikinci cildin dizi içerisindeki yeri vurgulanmakta, Çevirmenin Notları (20-21) bölümünde Grek/Yunan ve Pers/Fars/Iranlı terimlerinin kullanımına ilişkin onomastik açıklamalar yapılmaktadır. Giriş (23-36) bölümünde yazar, Doğu-Batı ilişkisi anlatılırken sıkça kullanılan "Batıı Değerler" ve "Şark Despotizmi" kavramları üzerinde durmakta, bu kavramların beraberinde getirdiği ayrıştırmaya değinmekte ve nihayetinde kültürlerin, halkların ve uygarlıkların önyargıya dayalı bir "Doğu-Batı" kalıbına sığdırılmasının, tarihi düzgün bir şekilde kavramanın önünde engel teşkil ettiğine vurgu yapmaktadır. Kaleme alınma amacının, yu-
\end{abstract}

\footnotetext{
*M.A., Akdeniz Üniversitesi, Akdeniz Uygarlıkları Araştırma Enstitüsü, Akdeniz Eskiçağ Araştırmaları Anabilim Dalı, Antalya. ozgeacar90@gmail.com
} 
karıda anılan bu ilk temasla başlayan ilişkilerin daima karmaşık olduğunu, ancak asla tek tarafı olmadığını gözler önüne sermek olarak belirlendiği bu eser, buradan sonra on bölüme ayrılmakta, Kaynakça ve Dizin bölümleri ile son bulmaktadır.

Kyros'un Mirası (37-52) başlıklı birinci bölümde ilk olarak antik İran’ın coğrafi arka planı üzerinde durulduktan sonra tarih öncesi devirden ve İranlıların bölgeye gelişinden bahsedilmektedir. Ardından Medler ve Persler arasındaki ilişkiler ile sonucunda Büyük Kyros tarafından Pers Imparatorluğu'nun kurulduğu çatışmalar aktarılmaktadır. Buna müteakiben bölüm Persepolis kentinin Pers hanedancılı̆ı̆na dair verdiği fikirlerin sunulmasıyla son bulmaktadır. Persler ve Yunanlar (53-88) başıkı ikinci bölümde Pers-Yunan ilişkilerinin ilk temas noktası tartışılmaktadır. Öncelikle, Yunan, Hellen ve Ion adlandırmaları Persler açısından ele alınmakta, özellikle Yunan ve Ion arasındaki farkı ayırt etmenin önemine vurgu yapılmaktadır. Sonrasında ise, Perslerin Ön Asya'ya ilk adımları, Lydia'nın fethi ve bu fetihle başlayan etkileşim süreci tartışımaktadır. Denizin Ötesindeki Ionlar (89-128) başlıklı üçüncü bölümde, Doğu ile Batı arasında bugün de süren sözde çatışmanın miladı olan Pers-Yunan Savaşları mercek altına alınmaktadır. Söz konusu savaşların konu edildiği modern kaynaklardaki Doğu karşıtlığı önyargısı, eserin geneline hâkim olan eleştiriye burada da maruz kalmaktadır. Şeytan Kral (129-156) başlıklı dördüncü bölümde yazar, Makedonyalı Büyük İskender'in en büyük eserleri olarak kabul edilen enternasyonalizm ve tek dünya düşüncelerinin İskender mi; yoksa onun yerle bir ettiği Pers Imparatorluğu tarafından mı yaratıldığı sorusuyla bir giriş yaparak bu bölüm kapsamında temelde neyi tartışacağını okuyucuya sezdirmektedir. İskender'in Pers İmparatorluğu üzerine yürüyüş süreci ele alınmakta ve bu süreçte Pers-Yunan ilişkileri analiz edilmektedir. "iranistik" Bir Çağ (157-201) başlıklı beşinci bölümde İskender'in ardından ortaya çıkan Hellenistik kralıkların yanında, batıda da Yeni-Pers krallıklarının kurulması, bu şekilde Perslerin kültürel etkilerinin her yere sinmesi, dolayısıyla İranistik bir dönem yaşanması konu edilmektedir. Bu noktada özellikle Karadeniz'deki Mithradates Hanedanlığı'ndan Mithradates VI Eupator'un Roma ile yaptığı savaşlar üzerinde durulmakta ve bölümün ilerleyen kısımlarında Kappadokia ve Kommagene kralıklarına da göndermeler yapılmaktadır. iki Süper Güç (202-222) başlıklı altıncı bölümde, Orta Asya'dan bu bölgeye gelen İranlı kabilelerin üçüncüsü ve sonuncusu olan Partlar ve onları izleyen Sasani Hanedanlığı'nın Roma ile aralarındaki çekişmeler yazar tarafından 'Akhaemenidlerin şaşaalı geçmişini diriltme çabaları' olarak yorumlanmakta ve bu çekişmelere ilişkin savaş anlatımları ile kitap genelindeki tarih anlatısı son bulmaktadır. Aydınlık ve Karanlık (223-244) başlıklı yedinci bölümde İran'a has dini düşünceler konu edilmekte, Zerdüştçülük, Mithraizm ve Manicilik öğretilerine ve son olarak İslamiyet'e değinilmektedir. Zerdüşt'ün Gölgesi (245-262) başlıklı sekizinci bölümde İran dinine özgü unsurların Anadolu'daki Hellenistik gelenekler ve Batı'ya aktarılan Hristiyanlıkla teması aydınlatılmaktadır. Düalizm Sorunu (263-286) başlıklı dokuzuncu bölümde, İran’a özgü dini düşüncelerin Avrupa'ya bulaşması ve beraberinde getirdikleri düalist düşüncenin burada aldığı şekiller üzerine yorum yapılmaktadır. Irani Bir Dünya (287-298) başlıklı son bölüm aynı zamanda kitabın sonuç bölümü niteliğini taşımakta ve İran'ın tek dünya düşüncesi özetlenmeye çalışılmaktadır.

Doğu-Batı çatışmasının başlangıcı olarak kabul gören Pers-Yunan Savaşları ve bu süreçte "Batılı Değerler"i tehdit eden Perslerin tarihsel ve kültürel boyutlarda ele alındığı bu eserde Pers Imparatorluğu'nun, bu kutuplaşmayı başlatan "Şark Despotizmi" değil, aksine iskender'e atfedilen "tek dünya" düşüncesinin yaratıcısı olduğu fikri sunulmaktadır. Ball, kolay anlaşılır anlatım tarzı ve sıkça yer verdiği şiirsel alıntılarıyla okuyucuyu dinlendirmekte ve onu zamandizinsel perspektif içinde Doğu-Batı ilişkileri üzerine alışımışın dışında eleştirel bir spekülasyona davet etmektedir. 